Clin Pediatr Endocrinol 1993;2(Suppl 2):21-29

Copyright (C1993 by The Japanese Society for Pediatric Endocrinology

\title{
Comparative Use of Immunological Methods \& Ligand Blotting of Insulin-like Growth Factor Binding Proteins in Serum and Other Biological Fluids
}

\author{
Ron G. Rosenfeld, Sharron E. Gargosky, Hung M. Pham, Kristin F. Wilson \\ and Linda C. Giudice
}

Departments of Pediatrics and, Obstetrics and Gynecology, Stanford University Medical School, Stanford, CA, USA

\begin{abstract}
There is controversy as to which methodology most accurately detects the Insulin-like growth factor binding proteins (IGFBPs). We have compared immunological and ligand binding techniques to assess the IGFBPs in serum from non-pregnant women and women in late pregnancy, fetal cord serum and amniotic fluid. A specific radioimmunoassay for IGFBP-3 measured mean levels of 3.5 and $3.7 \mu \mathrm{g} / \mathrm{ml}$ for non-pregnancy and pregnancy serum, respectively, $0.7 \mu \mathrm{g} / \mathrm{ml}$ for fetal cord serum and $5.1 \mu \mathrm{g} / \mathrm{ml}$ for amniotic fluid. In contrast, Western-ligand blot of fluid showed IGFBP-3 as a $40 \mathrm{kDa}$ doublet in non-pregnancy serum and fetal cord serum, unlike pregnancy serum or amniotic fluid, where IGFBP-3 was undetectable by standard blot analysis. However, analysis of fluids at 25-50 times more volume showed that IGFBP-3 was detectable as a $40 \mathrm{kDa}$ doublet in pregnancy serum and amniotic fluid. The molecular mass of immunoreactive IGFBP-3 was examined by Western-immunoblot, probed with antibody $\alpha$ IGFBP-3g1. As in Western-ligand blot, intact IGFBP-3 $(40 \mathrm{kDa})$ was easily detected in non-pregnancy serum and fetal cord serum, but required greater volumes of sample for detection in pregnancy serum and amniotic fluid. In addition, smaller immunoreactive fragments were found in all fluids: a faint 27 and $22 \mathrm{kDa}$ band was found in non-pregnancy serum and fetal cord serum, with more dominant bands of 31-27, 26, 25, 24 and $22 \mathrm{kDa}$ in pregnancy serum and 31-26, 25, 22, 19-17 kDa in amniotic fluid. To address the obvious discrepancies between ligand and immunological analysis, samples were assessed for IGFBP-3 protease activity. Non-pregnancy serum proteolyzed 14\% of the substrate, pregnancy serum $61 \%$, fetal cord serum $33 \%$, and amniotic fluid $50-61 \%$. Thus, fluids with apparently low IGFBP-3 by Western-ligand blot, but high IGFBP-3 by RIA, showed high levels of protease activity. Previously, IGFBP-proteases have been shown to degrade IGFBP to smaller fragments with a reduced affinity for IGF. We conclude that the discrepancy between ligand binding techniques and immunological techniques can be explained, at least in part, by the presence of IGFBP-protease activity.
\end{abstract}

Key words: insulin-like growth factor (IGF), protease, IGF binding protein (IGFBP).

Correspondence: Dr. Sharron E. Gargosky, Department of Pediatrics, Division of Pediatrics Endocrinology, Stanford University Medical School, Stanford, CA 94305-5119 USA
This work was supported in part by: DK 36054 and DK 28229 (RGR) and a grant from the American Diabetes Association (LCG, RGR).

SEG is a recipient of the CJ Martin Postdoctoral Fellowship, NH\&MRC, Australia. 


\section{Introduction}

The insulin-like growth factors (IGFs) are polypeptides that exert a wide range of mitogenic and differentiative effects at the cellular level [1]. IGFs circulate associated with IGF binding proteins (IGFBP). To date, six IGFBPs have been isolated and characterized on the basis of amino acid and DNA sequence [2]. IGFBP-1, 2, 4, 5 and 6 are the smaller IGFBPs (24-36 kDa), whereas IGFBP3 , the major serum IGFBP of $45 \mathrm{kDa}$, circulates as a $150 \mathrm{kDa}$ complex [3-5]. IGFBPs can modulate the action of IGFs in either an inhibitory mechanism (binding the IGF and preventing presentation to the cellular receptor), or by potentiating the action of IGF (enhancing cellular presentation or mediating non-receptor activation at the cell surface) $[1$, $6,7]$.

IGFBPs are generally examined by Western-ligand blot analysis. This characterization technique relies upon the stability and functionality of the IGFBPs following SDS PAGE and electrotransfer of proteins to nitrocellulose, and upon their subsequent ability to bind radiolabeled ligand [8]. Recently, the evaluation of IGFBPs in the serum of pregnant women has illustrated the inherent problems with this technique. IGFBP-3 is apparently absent by week eight of pregnancy as assessed by Western-ligand blot analysis [9, 10], but measurable by radioimmunoassay [4], as well as by indirect techniques that measure the IGF content of the $150 \mathrm{kDa}$ complex [11]. This discrepancy has been attributed to a pregnancy-associated IGFBPprotease $[9,12]$. The protease can degrade IGFBP-3 into smaller fragments that display a reduced affinity for IGF and are subsequently difficult to detect by techniques that rely upon ligand binding (ie, Western-ligand blots) [13] . The physiological significance of the pregnancy-associated IGFBP-protease is still controversial. Possibly, the partial proteolysis of IGFBP-3 by the IGFBP-protease may promote the release of IGF, thereby potentiating the bioavailability and bioactivity of IGFs.

We have measured and characterized IGFBP-3 in serum from non-pregnant and pregnant women, fetal cord serum and amniotic fluid. Specifically, we have: 1) measured the concentration of immuoreactive IGFBP-3 by means of a newly established specific radioimmunoassay; 2) characterized the ligand binding-form of IGFBP-3 by Western-ligand blot; 3) characterized the immunoreactive form(s) of IGFBP-3 by westernimmunoblot; and 4) quantitated the IGFBP. protease activity using two different sources of IGFBP-3.

\section{Methods}

\section{IGFBP-3 Radioimmunoassay}

Samples were assessed for immunoreactive IGFBP-3 as previously described [14]. In brief, assay samples (500 ul in total) consisted of: $50 \mathrm{ul}$ of a diluted sample, $\alpha$ IGFBP-3g1 antiserum (50 ul of $1 / 1000$ dilution), 125 I-IGFIGFBP- 3 complex $(10,000 \mathrm{cpm} / 50 \mathrm{ul})$, and 350 ul of buffer containing BSA. Following an incubation for $18 \mathrm{~h}$ at $4 \mathrm{C}$, samples were incubated with $50 \mathrm{ul}$ of both $4 \%$ normal rabbit serum and goat anti-rabbit $\lg$ for $30 \mathrm{~min}$ at $22 \mathrm{C}$, after which $1 \mathrm{ml}$ of $6 \%$ PEG was added. The samples were centrifuged immediately at $3000 \mathrm{rpm}$ for $30 \mathrm{~min}$ at $4 \mathrm{C}$, the supernatant was aspirated and the pellets counted.

The mean specific and non-specific binding were $42 \pm 3 \%$ and $7 \pm 2.5 \%$, respectively. The minimal detectable concentration was $0.66 \mathrm{ng} /$ tube or $3.5 \mathrm{ng} / \mathrm{ml}$, and the intra- and inter-assay co-efficients of variation were $4.4 \%$ and $12 \%$, respectively.

\section{Western Analysis}

1) Ligand blot

Samples were subjected to Western-ligand blot analysis as described by Hossenlopp et al. [8]. Samples were subjected to SDSpolyacrylimide gel electrophoresis, transferred 
to nitrocellulose and probed with radiolabel IGF-I and IGF-II. The treated nitrocellulose was exposed to x-ray film for 3-7 days at $-70 \mathrm{C}$.

2) Immunoblot using chemiluminescence

As previously described [14], samples were subjected to Western-ligand blot analysis as outlined above, but were probed with $\alpha$ IGFBP-3g1 antiserum. The secondary detection system utilized a goat anti-rabbit IgG conjugated with horseradish peroxidase and chemiluminescent reagents purchased from Amersham (ECL kit). Nitrocellulose was exposed to X-ray film for $20-40 \mathrm{~min}$ at room temperature.

\section{IGFBP-3 Protease Assay}

Fluids were assessed for IGFBP-3 protease activity [12]. Following an incubation with iodinated E. coli-derived IGFBP-3, fluids were electrophoresed and the gels dried under vacuum. The gels were exposed to X-ray film for $12-18 \mathrm{~h}$ at $-70 \mathrm{C}$. The autoradiographic intensity of the bands was determined with a Laser densitometer scanner (Pharmacia, LKB). The \% proteolysis was calculated as the optical density of IGFBP-3 fragments/ total IGFBP-3-related densities.

\section{Results}

The measurement of immunoreactive IGFBP-3 in serum (non-pregnancy, pregnancy and fetal cord) and amniotic fluid required parallelism between the purified peptide and fluid; the slopes of the curves were virtually superimposable, ranging from -0.39 to -0.42 (Figure 1, upper panel). The concentrations of IGFBP-3 in the various fluids are shown in Figure 1 (lower panel). Non-pregnancy serum contained $3556 \pm 508 \mathrm{ng} / \mathrm{ml}$ (mean \pm $\mathrm{SEM})$; pregnancy serum, $3718 \pm 842 \mathrm{ng} / \mathrm{ml}$; fetal cord serum, $753 \pm 101 \mathrm{ng} / \mathrm{ml}$; and amniotic fluid, $5150 \pm 688 \mathrm{ng} / \mathrm{ml}$.

In order to characterize the molecular mass of the IGFBPs, fluids were assessed by

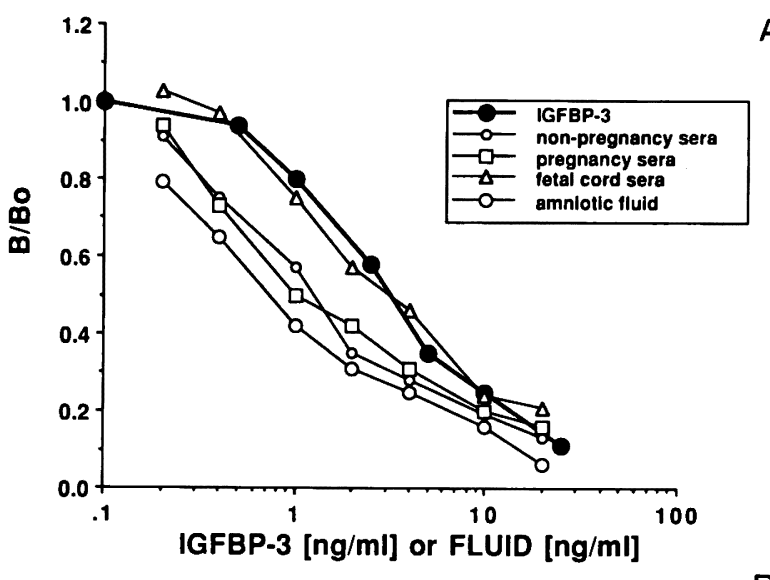

A

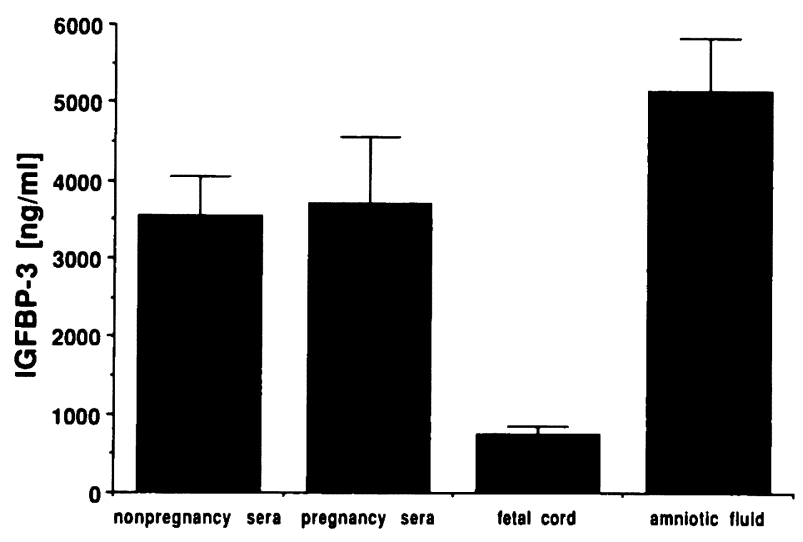

Fig 1. Radioimmunoassay (RIA) of IGFBP-3

Panel A: Parallelism between glycosylated IGFBP-3 and biological fluids.

Samples were serially diluted and measured in the IGFBP-3 RIA. The y-axis represents the sample binding divided by the total specific binding, and the $\mathrm{x}$-axis, the sample dilution $(\mu \mathrm{l} / \mathrm{ml})$ versus IGFBP-3 (ng/ml).

Analysis were repeated in five independent experiments at 7-8 dilutions, and each dilution was measured in triplicate.

Non-pregnancy and pregnancy serum (16-21 weeks) are represented by a mean of pools containing 3 individual sera. Fetal cord serum is represented as a mean of 3 individuals, and amniotic fluid (15-21.5 weeks) represents a mean of 5 individual samples. Panel B: Concentration of immunoreactive IGFBP-3.

Data represent means \pm SEM for an average of 3 experiments, where samples were measured at three concentrations in triplicate.

Western-ligand blot (Figure $\alpha$ IGFBP-3gl 2A) and Western-immunoblot using $\alpha$ IGFBP-3gl antiserum (Figure 2B). Sera from nonpregnant women Western-ligand blotted as a $44-35 \mathrm{kDa}$ doublet with a similar molecular mass to glycosylated IGFBP-3, as well as faint 


\section{ROSENFELD et $a l$.}

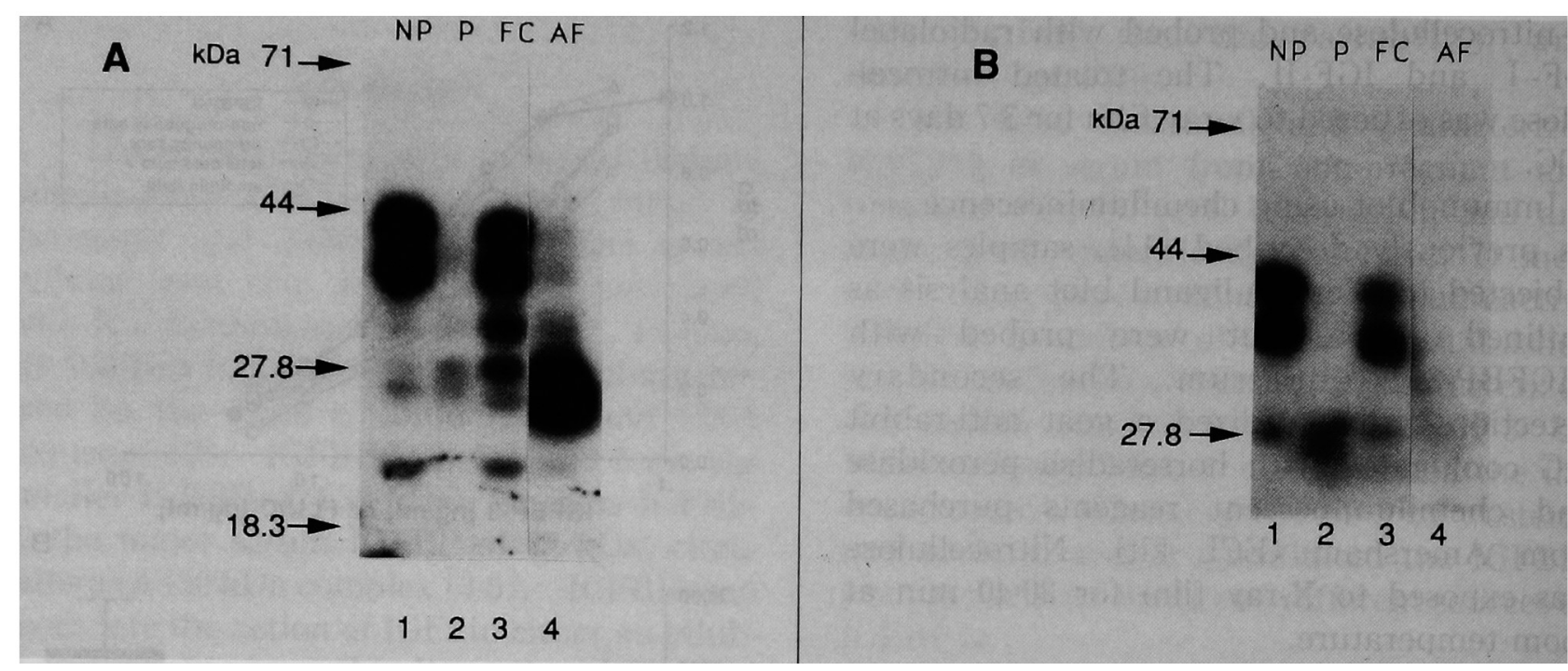

Fig 2. Characterization of IGFBPs

Panel A: Western-ligand blot

Samples were incubated with SDS loading buffer, and molecular weight markers were incubated with reducing SDS-loading buffer, and then subjected to electrophoresis and to electrotransfer, and probed with radiolabelled IGF. I and IGF.II. The treated nitrocellulose was autoradiographed for 8 days.

The molecular mass markers are indicated. The fluids were pools of ' $n$ ' individual samples: lane $1, \mathrm{NP}$ =non-pregnancy serum $(n=3,2 \mu 1)$; lane $2, P=$ pregnancy serum (16-21 weeks of gestation, $n=3,2 \mu 1)$; lane 3 , FC=fetal cord sera $(n=2,2 \mu 1)$; and $A F=$ amniotic fluid (18 weeks gestation, $n=3,1 \mu 1$ ).

All samples were treated on one gel. This is one representative gel of these biological fluids and has been repeated 5 times.

$32,28-27$ and $22 \mathrm{kDa}$ IGFBPs (Figure $2 \mathrm{~A}$, lane 1). Of these IGFBPs, the $44-35 \mathrm{kDa}$ doublet and to a lesser extent the $28 \mathrm{kDa}$ band reacted with $\alpha$ IGFBP-3g1 antisera (Figure 2B, lane 1). Western-ligand blot of fetal cord serum (2 ul) produced a similar pattern to non-pregnancy serum (Figure 2A, lane 3): a $44-35 \mathrm{kDa}$ IGFBP-3 doublet, as well as $32,28,26$ and 22 $\mathrm{kDa}$ IGFBPs. Western-immunoblot with IGFBP-3 antisera showed reactivity with the $40 \mathrm{kDa}$ doublet, as well as the $28 \mathrm{kDa}$ IGFBP band (Figure 2B, lane 3). Thus, intact 44-35 $\mathrm{kDa}$ IGFBP-3, as well as a $28 \mathrm{kDa}$ immunoreactive fragment was seen in non-pregnancy and fetal cord serum. In contrast, sera from women between weeks $16-18$ of pregnancy ( 2 ul) contained little $44-35 \mathrm{kDa}$ IGFBP.
Panel B: Western-immunoblot with $\alpha$ IGFBP-3g1 antisera

Samples were electrophoresed, electrotransfered, and incubated with antiserum. Binding was detected following incubation with goat antirabbit, horse radish peroxidase conjugated IgG and fluorescent sub. strates. The nitrocellulose was exposed to X-ray film at room temperature for $20 \mathrm{~min}$.

The molecular mass markers are indicated. The fluids were pools of ' $n$ ' individual samples: lane 1 , NP =non-pregnancy serum $(n=3,2 \mu 1)$; lane $2, P=$ pregnancy serum (16-21 weeks of gestation, $\mathrm{n}=3,2 \mu 1)$; lane 3 , FC=fetal cord sera $(n=2,2 \mu 1)$; and $A F=a m n i o t i c$ fluid ( 18 weeks gestation, $n=3,1 \mu 1$ ).

All samples were treated on one gel. This is one representative gel of the fluids and has been repeated twice.

Instead, very faint 32 and $29-26 \mathrm{kDa}$ IGFBPs were visable by ligand blot (Figure 2A, lane 2). Of these bands, only the broad $28-26 \mathrm{kDa}$ IGFBP reacted with $\alpha$ IGFBP-3g1 antisera: no intact IGFBP-3 was detected (Figure $2 \mathrm{~B}$, lane 2). Likewise, amniotic fluid Western-ligand blotted as a faint $32 \mathrm{kDa}$ and $42-37 \mathrm{kDa}$ doublet, as well as a dominant band at 30-24 $\mathrm{kDa}$. Only the $28 \mathrm{kDa}$ band reacted with the $\alpha$ IGFBP-3g1 antiserum (Figure 2A \& B, lane 4). These results appeared to contradict the high IGFBP-3 levels detected in amniotic fluid by RIA.

To address the possibility that pregnancy serum and amniotic fluid contained IGFBP-3, possibly at low concentrations or with reduced affinity for ligand, we analysed increasing 


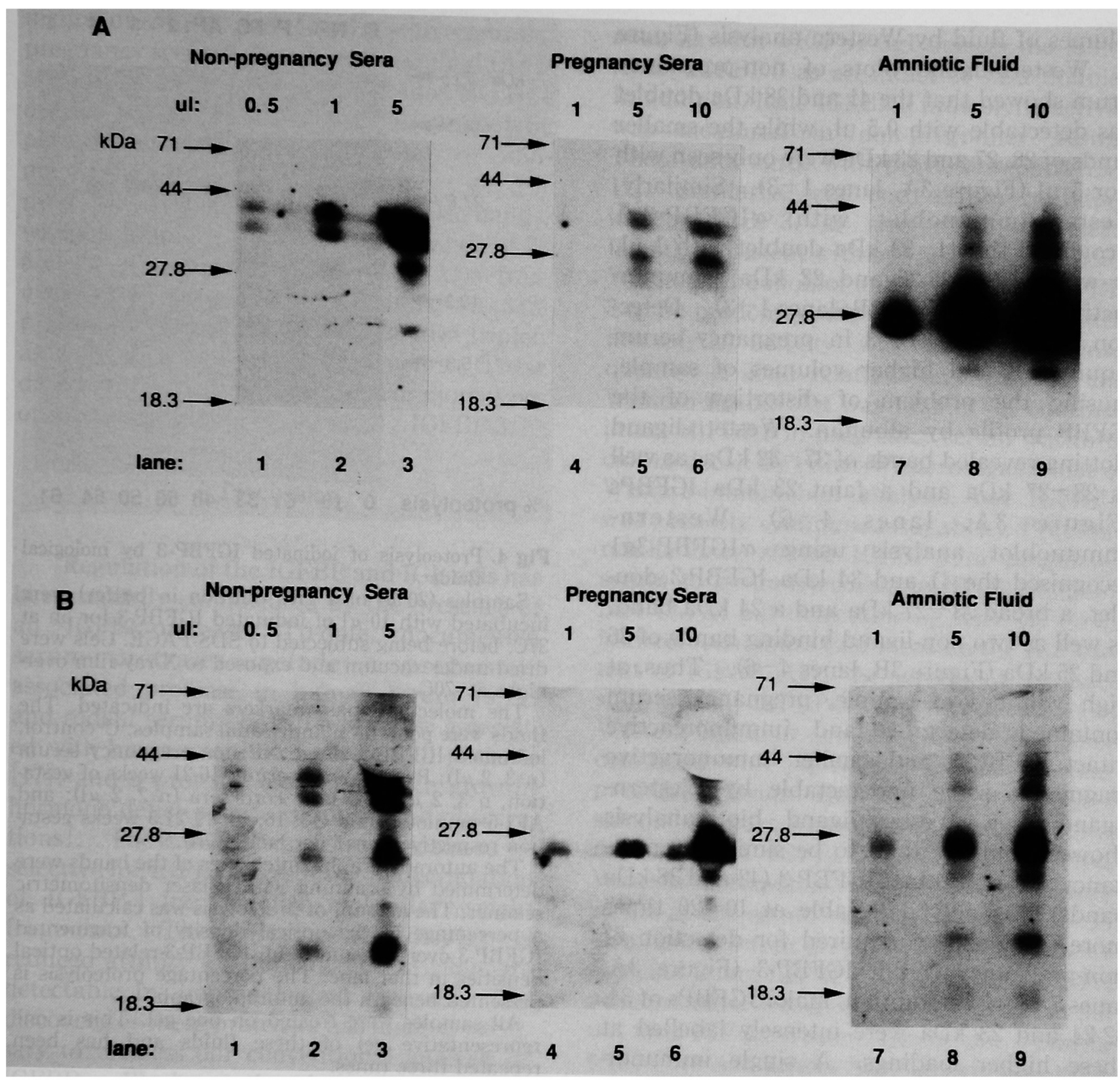

Fig 3. Increasing concentration of fluid for IGFBP characterization

\section{Panel A: Western-ligand blot}

Samples were treated as described for Figure 2A.

The nitrocellulose was exposed to X-ray film for three days.

The molecular mass markers are indicated. The fluids were pools of ' $n$ ' individual samples: lanes 1-3, non-pregnancy serum $(n=3)$ at $0.5,1$, and $5 \mu 1$; lanes $4-6$, pregnancy serum (16-21 weeks of gestation, $n=3$ ) at $1,5,10 \mu \mathrm{l}$; and lanes 7-9, amniotic fluid (18 weeks gestation, $\mathrm{n}=3$ ) at $1,5,10 \mu 1$.

All gels were prepared and treated identically. This is one representative set of experiments and has been repeated three times.
Panel B: Western-immunoblot with $\alpha$ IGFBP-3g1

Samples were treated as described in Figure $2 \mathrm{~B}$.

The nitrocellulose was exposed to $\mathrm{x}$-ray film at room temperature for $40 \mathrm{~min}$.

The molecular mass markers are indicated. The fluids were pools of ' $n$ ' individual samples: lanes 1-3, non-pregnancy serum $(\mathrm{n}=3)$ at $0.5,1$, and $5 \mu 1$; lanes $4-6$, pregnancy serum (16-21 weeks of gestation, $n=3$ ) at $1,5,10 \mu \mathrm{l}$; and lanes 7-9, amniotic fluid (18 weeks gestation, $\mathbf{n}=3)$ at $1,5,10 \mu 1$.

All gels were prepared and treated identically. This is one representative set of experiments and has been repeated three times. 
volumes of fluid by Western analysis (Figure 3). Western-ligand blots of non-pregnancy serum showed that the 41 and $38 \mathrm{kDa}$ doublet was detectable with $0.5 \mathrm{ul}$, while the smaller bands of 28,27 and $23 \mathrm{kDa}$ were only seen with 1 or 5 ul (Figure 3A, lanes 1-3). Similarly, Western-immunoblot with $\alpha$ IGFBP-3g1 recognised the $44-33 \mathrm{kDa}$ doublet with $1 \mathrm{ul}$, as well as $31,28-26$ and $22 \mathrm{kDa}$ immunoreactive bands (Figure 3B, lanes 1-3). Detection of intact IGFBP-3 in pregnancy serum required 10-fold higher volumes of sample, causing the problem of distortion of the IGFBP profile by albumin. Western-ligand blotting revealed bands of $37-32 \mathrm{kDa}$, as well as $28-27 \mathrm{kDa}$ and a faint $23 \mathrm{kDa}$ IGFBPs (Figure 3A, lanes 4-6). Westernimmunoblot analysis using $\alpha$ IGFBP-3g1 recognised the 41 and $34 \mathrm{kDa}$ IGFBP-3 doublet, a broad $31-27 \mathrm{kDa}$ and a $24 \mathrm{kDa}$ band, as well as two non-ligand binding bands of 26 and $25 \mathrm{kDa}$ (Figure 3B, lanes 4-6). Thus, at high volumes of sample, pregnancy serum contained detectable and immunoreactive intact IGFBP-3, and smaller immunoractive fragments, some undetectable by Westernligand blot. Western-ligand blot analysis showed amniotic fluid to be similar to pregnancy serum. Intact IGFBP-3 (42 and $38 \mathrm{kDa}$ bands) was only detectable at 10-20 times more sample than required for detection of non-pregnancy serum IGFBP-3 (Figure 3A, lanes 7-9). In addition, major IGFBPs of 34, $32-24$ and $23 \mathrm{kDa}$ were intensely labelled at these higher loadings. A single immunoreactive band of $27-28 \mathrm{kDa}$ was detected at $1 \mu 1$, but at higher sample volumes, the $43-37 \mathrm{kDa}$ IGFBP-3 doublet, as well as a faint $33 \mathrm{kDa}$ band, a dominant $31-26 \mathrm{kDa}, 25 \mathrm{kDa}, 22 \mathrm{kDa}$ and $19-17 \mathrm{kDa}$ bands were visible (Figure $3 \mathrm{~B}$, lanes 7-9). Thus, amniotic fluid also contained low levels of intact $40 \mathrm{kDa}$ IGFBP-3, as well as many smaller immunoreactive fragments.

The discrepancies between western-ligand blot and RIA may be due to the presence on an IGFBP-protease, which has been shown to degrade IGFBP-3 into smaller fragments that

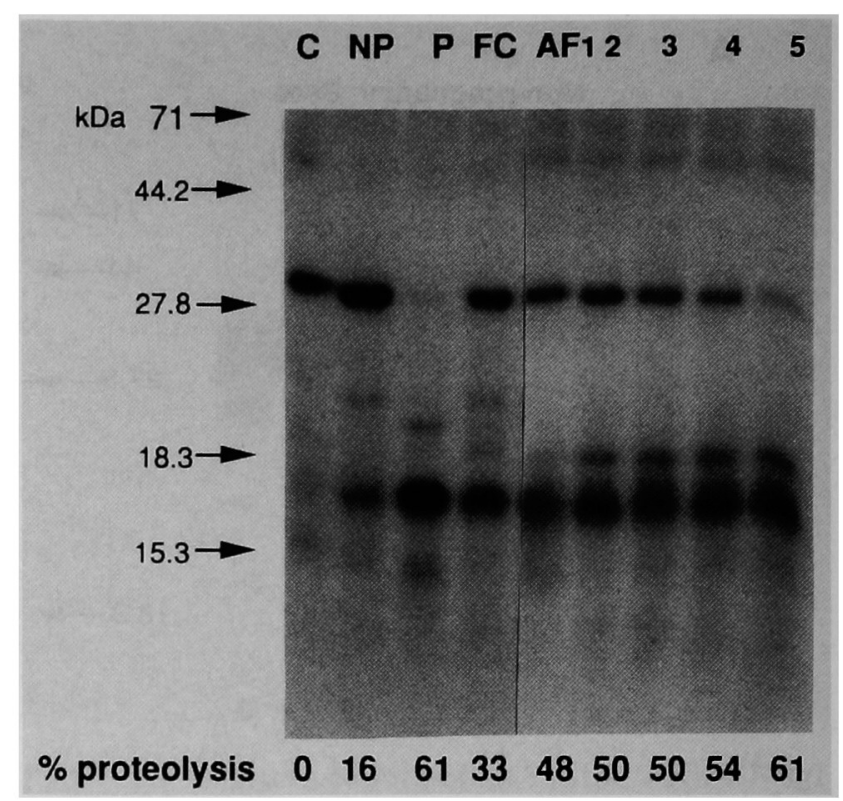

Fig 4. Proteolysis of iodinated IGFBP-3 by biological fluids

Samples (20 $\mu 1$ of a 1:10 dilution in buffer) were incubated with $10 \mu \mathrm{l}$ of iodinated IGFBP-3 for $5 \mathrm{~h}$ at $37 \mathrm{C}$, before being subjected to SDS-PAGE. Gels were dried under vacuum and exposed to X-ray film overnight at $-70 \mathrm{C}$.

The molecular mass markers are indicated. The fluids were pools of ' $n$ ' individual samples: $C=$ control, iodinated IGFBP-3 alone; $\mathrm{NP}=$ non-pregnancy serum $(\mathrm{n}=3,2 \mu 1) ; \mathrm{P}=$ pregnancy serum $(16-21$ weeks of gestation, $\mathrm{n}=3,2 \mu 1)$; $\mathrm{FC}=$ fetal cord sera $(\mathrm{n}=2,2 \mu 1)$; and AF1-5=amniotic fluid $(15,16,18,1921.5$ weeks gestation respectively, $n=1$ per lane, $2 \mu 1)$.

The autoradiographic intensities of the bands were determined by scanning with a laser densitometric scanner. The amount of proteolysis was calculated as a percentage of the optical density of fragmented IGFBP-3 over the sum of all IGFBP-3-related optical densities in that lane. The percentage proteolysis is presented beneath the autoradiograph.

All samples were treated on one gel. This is one representative gel of these fluids and has been repeated three times.

display reduced affinity for IGFs [13]. Consistently, both amniotic fluid and pregnancy serum displayed high immunoreactive IGFBP. 3 , but intact IGFBP-3 was difficult to detect, and only smaller immunoreactive fragments were observed. Thus, to assess for proteolytic activity, fluids were incubated with iodinated IGFBP-3, electrophoresed, dried and autoradiographed (Figure 4). Serum from non-pregnancy serum (NP) showed the least proteolysis and yeilded frag- 
ments of 23,18 and $15 \mathrm{kDa}$. In contrast, pregnancy serum (P) and amniotic fluid (AF15) contained proteases that degraded $50-60 \%$ of the IGFBP-3 substrate. The proteolytic pattern also differed from that of nonpregnancy serum. Pregnancy serum produced 21.5, 20, 18 and $15 \mathrm{kDa}$ bands, whereas amniotic fluid produced bands of 20 and $18 \mathrm{kDa}$ with faint 16 and $15 \mathrm{kDa}$ fragments. Fetal cord serum resulted in $33 \%$ proteolysis with a $23,21.5$ and $20 \mathrm{kDa}$ triplet, as well as 18 and $15 \mathrm{kDa}$ fragments. These data suggest the presence of one or more types of protease capable of degrading IGFBP-3.

\section{Discussion}

Regulation of the IGFBP and IGF axis has been recently complicated by the presence of an IGFBP-protease. To-date, documented serum proteases include a pregnancyassociated protease in human serum $[9,10]$ and rodent serum $[15,16]$, a protease associated with human serum of severely ill patients [17], and a protease associated with growthhormone deficient rats [unpublished observations]. These IGFBP-proteases appear to be selective for IGFBP-3, resulting in degradation of IGFBP-3 into smaller molecular weight fragments. These fragments display a reduced affinity for radioligand [13], but are detectable by immunological analysis. The discovery of these proteases has made it necessary to reassess our conventional analysis of IGFBPs. We have, therefore, compared the ability of ligand-dependent and immunological techniques, as well as the recently developed IGFBP-protease assay, to detect the IGFBPs in non-pregnancy, pregnancy and fetal cord serum, as well as amniotic fluid.

In non-pregnancy serum, we have found that IGFBP-3 is detected by RIA at $3.5 \mu \mathrm{g} / \mathrm{ml}$, similar to levels reported by Blum and coworker [18], but lower than reported by Baxter and Martin [6]. IGFBP-3 in nonpregnancy serum is found on Western-ligand blot as a $40 \mathrm{kDa}$ doublet, and immunoblot analysis with $\alpha$ IGFBP-3g1 detects the majority of IGFBP-3 as an intact $40 \mathrm{kDa}$ doublet. In addition, little IGFBP-3 proteolytic activity was measured in non-pregnancy serum. These data agree with previous reports $[5,6$, 11]. Similarly, fetal cord serum contained intact IGFBP-3, as assessed by Westernligand, consistent with our previous data [19]. Western-immunoblot analysis showed IGFBP3 to be predominantly intact, and again little proteolytic activity was observed. Consequently, a good relation between RIA and Western-ligand blot was found. In contrast, intact IGFBP-3 in pregnancy serum was difficult to detect by either Western-ligand blot or Western-immunoblot analysis, but IGFBP-3 was readily immunoassayable. Previous results have shown IGFBP-3 in pregnancy serum to be undetectable by Western-ligand blot $[9,10]$, but detectable by RIA [6] or by indirect techniques that measure the IGF content of IGFBP [11]. In agreement, we have shown that IGFBP-3 was undetectable by Western-ligand or -immunoblot analysis when compared with equivalent volumes of nonpregnancy serum. However, when increased sample volumes were loaded (up to 10 times more), intact IGFBP-3 could be detected. Western-immunoblot analysis of pregnancy serum at low serum volumes displayed $31-27$ $\mathrm{kDa}$ bands, but at greater sample volumes we detected intact IGFBP-3 and smaller IGFBP-3 immunoreactive fragments, some of which did not bind IGF by Western-ligand blot. Consistently, we and others have shown that pregnancy serum contains a protease capable of fragmenting IGFBP-3 in vitro $[9,12]$. Thus, the discrepancy between RIA and Westernligand blot can be explained, at least in part, by the presence of an IGFBP-3 protease. This phenomenon was not limited to pregnancy serum. Amniotic fluid displayed very low levels of intact IGFBP-3 by western-ligand or western-immunoblot analysis, yet RIA measured IGFBP-3 at $5 \mu \mathrm{g} / \mathrm{ml}$. In agreement, Baxter and Martin have previously reported high levels of immunoassayable IGFBP-3 in amniotic fluid, and have purified 
IGFBP-3 from this fluid [20]. Analysis with greater sample loading demonstrated the presence of intect IGFBP-3, as well as smaller immunoreactive fregments, some of which were only detected by Western-immunoblot analysis. Further, amniotic fluid was found to contain high levels of IGFBP-3 proteolytic activity. Discrepancies between Westernligand, Western-immunoblot and RIA thus appear to be readily explained by the presence of IGFBP-proteases. In both pregnancy serum and amniotic fluid: (a) IGFBP-3 was measurable by RIA; (b) low levels of intact IGFBP-3 were detected by Western-ligand or Western-immunoblot analysis; (c) smaller molecular weight fragments, undetectable by ligand binding techniques, were only detected with immunological analysis; and (d) pure IGFBP-3 substrate was proteolysed by these biological fluids.

Clearly all techniques are important in the characterization of IGFBPs. While liganddependant techniques reveal the biologically active IGFBPs, RIA and Western-immunoblot analysis identifiy the immunoreactive forms of IGFBP-3. In addition, the IGFBP-3 protease assay has become invaluable in the final analysis, to demonstrate the presence of the confounding effect of proteolytic activity.

\section{References}

1. Rosenfeld RG., Lamson G., Pham H., Oh Y., Conover C., DeLeon D., et al. Insulinlike growth factor-binding proteins. Rec. Prog. Hormone Res. 1991; 46: 99-163.

2. Ballard F., Baxter R., Binoux M., Clemmons D., Drop S., Hall K., et al. On the nomenclature of IGF binding proteins. 1989; Acta Endocrinol. 121: 751-2.

3. Martin JL \& Baxter RC. Insulin-like growth factor-binding protein from human plasma: purification and characterization. 1986; J. Biol. Chem. 261: 8756-60.

4. Baxter RC \& Martin JL. Radioimmunoassay of growth hormone dependent insulinlike growth factor binding protein in human plasma. 1989; Prog. Growth Factor Res. 1: 49-68.

5. Baxter RC., Martin JL \& Beniac VA. High molecular weight insulin-like growth factor binding protein complex: purification and properties of the acid-labile subunit from human serum. 1989; J. Biol. Chem. 264: 11843-8.

6. Neely EK \& Rosenfeld RG. Insulin-like growth factor (IGFs) reduce IGF-binding protein-4 (IGFBP-4) concentration and stimulate IGFBP-3 independently of IGF receptors in human fibroblasts and epidermal cells. 1992; Endocrinol. 130: 985-93.

7. Blum WF, Jenne EW., Reppin F., Jietzmann K., Ranke MB \& Bierich JR. Insulinlike growth factor- I (IGF. I )-binding protein complex is a better mitogen than free IGF- I . 1989; Endocrinol. 125: 766-72.

8. Hossenlopp P., Seurin D., Segovia-Quinson B., Hardouin S \& Binoux M. Analysis of insulin-like growth factor binding proteins using Western-ligand blot: use of the method for titration of the binding proteins and competitive binding studies. 1986; Anal. Biochem. 154: 138-43.

9. Giudice LC., Farrell EM., Pham H., Lamson G \& Rosenfeld RG. Insulin-like growth factor binding proteins in maternal serum throughout gestation and in the puerperium: effects of a pregnancy-associated serum protease activity. 1991; J. Clin. Endocrinol. Metab. 71: 806-17.

10. Gargosky SE., Owens PC., Walton PE., Robinson JR., Wallace JC \& Ballard FJ. Circulating levels of insulin-like growth factors increase and molecular forms of their serum binding proteins change with human pregnancy. 1990; Biochem. Biophys. Chem. Acta. 170: 1157-63.

11. Gargosky SE., Owens PC., Walton PE., Owens JA., Robinson JR., Wallace JC \& Ballard FJ. Increased concentrations of insulin-like growth factors (IGF. I and IGFII) in serum from pregnant women exist predominantly in the $150 \mathrm{kDa}$ IGF-binding protein. 1992; J. Endocrinol. 131: 491-7.

12. Lamson GL., Giudice LC \& Rosenfeld RG. 
A simple assay for proteolysis of IGFBP-3. 1991; J. Clin. Endocrinol. Metab. 72: 13913.

13. Hossenlopp P., Seurin B., Lassarre C., Roghani M., Beddon M \& Binoux M. Evidence for enymatic degradation of insulinlike growth factor binding proteins in the 150 kda complex. 1990; J. Clin. Endocrinol Metab. 71: 979-85.

14. Gargosky SE., Pham H., Wilson KF., Liu F., Guidice LC \& Rosenfeld RG. Measurement and characterization of insulin-like growth factor binding protein-3 in human biological fluids: discrepancies between radioimmunoassay and ligand blotting. 1992: Endocrinol. 131: 3041-60.

15. Gargosky SE., Walton PE., Owens PC., Wallace JC \& Ballard FJ. Insulin-like growth factor- I (IGF- I) and IGF-binding proteins both decline in the rat during late pregnancy. 1990; J. Endocrinol. 127: 383-90.

16. Fielder PJ., Thordarson G., Talamantes $F$ \& Rosenfeld RG. Characterization of insulin-like growth factor binding proteins (IGFBPs) during gestation in mice: effects of hypophysectomy and IGFBP-specific protease activity. 1990; Endocrinol. 127: 2270-80.

17. Holly JMP., Davies SC., Cotterill AM.,
Coulson VJ., Ross RJM., Miell JP., et al. Severe illness induced an IGFBP-3 specific protease in the circulation; the activity of which is nutritionally dependent. 1991; 2nd International IGF symposium (San Francisco) Abstract C48.

18. Blum WF., Ranke MB., Kietzmann K., Gauggel E., Ziesel HJ \& Bierich JR. A specific radioimmunoassay for the growth hormone dependent somatomedin-binding protein: its use for diagnosis of $\mathrm{GH}$ deficiency. 1990; J. Clin. Endocrinol. Metab. 70: $1292-8$.

19. Crystal RA \& Giudice LC. Insulin-like growth factor binding protein (IGFBP) profiles in human fetal cord sera: ontogeny during gestation and differences in newborns with intrauterine growth retardation (IUGR) and large for gestational age (LGA) newborns. 1991; In: Modern Concepts of Insulin-like growth factors, EM. Spencer, Ed., Elsevier Science Publishing Co. Inc. pp.395-408.

20. Baxter RC., Martin JI \& Wood MH. Two immunoreactive binding proteins for insulin-like growth factors in human amniotic fluid: relationship to fetal maturity. 1987; J. Clin. Endocrinol. Metab. 65: 42331. 